\title{
Kandungan Merkuri dan Asam Sianida Pada Kerang Polymesoda sp di Teluk Kao Halmahera Utara
}

\author{
Reni Tyas Asrining Pertiwi \\ Manajemen Sumberdaya Perairan, Fakultas Perikanan dan Ilmu Kelautan, Universitas \\ Khairun \\ Email: renityasasrining@gmail.com \\ Manuscript received: 12-03-2018 Revision accepted: 20-05-2018
}

\begin{abstract}
Abstrak
Kesehatan manusia sebagian besar ditentukkan oleh makanannya. Makanan yang disarankan harus memenuhi kebutuhan gizi, rendah akan mikroorganisme patogen, demikian juga dengan kontaminan kimia (Marti et al., 2007). Menurut Simangge, (2011) beberapa jenis ikan yang telah diteliti di Teluk Kao dalam tingkatan membahayakan karena mengandung sianida. Sumber protein lain yang telah banyak dimanfaatkan oleh masyarakat sekitar Teluk Kao yaitu kerang Kepah (Polymesoda sp). Tujuan penelitian ini yaitu ingin mengkaji kandungan merkuri dan asam sianida pada kerang kepah Polymesoda $s p$ yang di konsumsi oleh masyarakat sekitar Teluk Kao. Dengan mengetahui hasil kajian ini diharapkan hal dapat mengartikan tingkat keamanan kerang kepah Polymesoda sp layak tidaknya untuk dikonsumi oleh manusia. Metode yang digunakan untuk mengetahui kandungan merkuri dalam kerang kepah Polymesoda sp yaitu AAS dengan menggunakan pereaksi aquaregia dan analisis kandungan asam sianida pada kerang dengan menggunakan metode argentometri dengan pereaksi $\mathrm{AgNO}_{3}$. Hasil yang didapatkan yaitu kandungan merkuri $(1.24-3.49 \mathrm{mg} / \mathrm{kg})$ dan asam sianida $(14.55-24.11 \mathrm{mg} / \mathrm{kg})$ pada Polymesoda $\mathrm{sp}$ di Teluk Kao telah melebihi ambang batas yang telah ditetapkan yaitu $0.5 \mathrm{mg} / \mathrm{kg}$ untuk merkuri dan 1.5 untuk sianida (WHO, 2004). Hal ini mengartikan bahwa kerang kepah Polymesoda sp di Teluk Kao tidak layak untuk dikonsumsi.
\end{abstract}

Kata Kunci : Asam Sianida, Merkuri, Polymesoda sp

\begin{abstract}
Human health is largely determined by the diet. A recommendable diet should be able of providing sufficient nutrients containing low levels of pathogenic microorganisms, as well as chemical contaminants (Marti et al., 2007). According to Simangge, (2011) several species of fish that have been studied in Kao Bay are in dangerous levels because cyanide contains. Another source of protein that has been widely utilized by the community around the Bay of Kao is Kepah (Polymesoda sp). The purposes of this research were to study the content of mercury and cyanide acid on Polymesoda sp which were consumed by the people around Kao Bay. By knowing the result it's expected could contributing the meaning of feasible of Polymesoda $s p$ were consumed by human. The method used to determine mercury content in Polymesoda sp by using AAS method with aquaregia reagent and analysis of cyanide acid by using argent metric method with AgNO3 reagent. The results obtained mercury content in Polymesoda $s p$ were $1.24-3.49 \mathrm{mg} / \mathrm{kg}$ and cyanide acid $14.55-24.11 \mathrm{mg} / \mathrm{kg}$ ). It's had exceeded the threshold set of $0.5 \mathrm{mg} / \mathrm{kg}$ for mercury and 1.5 for cyanide WHO, 2004). This means that Polymesoda sp in Kao Bay are not feasible for consumption.
\end{abstract}

Keywords: Cyanide acid, Mercury, Polymesoda sp 


\section{PENDAHULUAN}

Kawasan pesisir dan laut Teluk Kao memiliki kekayaan sumberdaya hayati dan non hayati yang cukup tinggi. Kekayaan sumberdaya non hayati berupa berbagai jenis mineral bahan tambang berupa emas dan perak. Besarnya potensi emas di kawasan tersebut menjadi daya tarik berbagai pihak untuk mengekploitasi, baik secara legal maupun ilegal. PT Nusa Halmahera Mineral merupakan salah perusahaan yang mengantongi izin dari pemerintah untuk melakukan pengeksplorasian dan penambangan emas tanpa izin yang merupakan penambangan illegal yang dilakukan oleh masyarakat. Keberadaan tambang tersebut menjadi sumber mata pencaharian bagi masyarakat sekitar, baik pribumi maupun pendatang, serta menjadi salah satu sumber PAD yang cukup besar bagi pembangunan Kabupaten Halmahera Utara. Besarnya manfaat ekonomi yang didapatkan tidak dapat menutupi dampak negatif yang ditimbulkan bagi lingkungan dan kesehatan masyarakat yang ada di sekitarnya. Penggunaan berbagai bahan kimia seperti merkuri dan sianida dalam proses pengekstraksian emas menyumbangkan limbah bersama dengan lumpur yang dibuang di sepanjang sungai yang kemudian bermuara di laut (Simange, 2011).

Logam berat yang mengalir masuk ke dalam ekosistem laut dapat mengganggu keanekaragaman spesies dan ekosistem pada tingkatan daya racun dan akumulasi terhadap spesies (Matta et al., 1999). Berdasarkan laporan Dinas Kelautan dan Perikanan (2007) dalam Simange (2011) menyatakan bahwa sedimen yang masuk ke laut di duga mengandung bahan pencemar logam berat dan sianida yang telah melebihi ambang batas yang diperbolehkan, sehingga daerah tersebut tidak bisa dikembangkan sebagai areal peruntukkan budidaya perikanan.

Kesehatan manusia sebagian besar ditentukkan oleh makanannya. Makanan yang disarankan harus memenuhi kebutuhan gizi, rendah akan mikroorganisme patogen, demikian juga dengan kontaminan kimia (Marti et al., 2007). Merkuri dimasukkan ke dalam salah satu elemen beracun untuk kesehatan dan lingkungan (Niazi et al., 2009). Distribusi merkuri dapat menyebabkan keracunan dan kematian pada kehidupan (Ye et al., 2008). Karena merkuri dapat terakumulasi dalam organ vital dan jaringan seperti hati, otak, jantung serta merupakan faktor biomagnifkasi yang dapat menyebabkan efek yang besar terhadap manusia dan organisme lainnya yang mengonsumsi ikan (Murata, 2007). Merkuri di alam, dalam perairan dapat ditemukan dalam dua bentuk yaitu merkuri dan metil merkuri. Tingkat racun merkuri tergantung pada konsentrasi dan bentuk senyawa kimiawinya. Secara toksikologi, tingkat daya racun merkuri organik lebih tinggi dibandingkan dengan merkuri anorganik. Terutama tingginya daya larut merkuri organik pada lemak dan rendahnya kemampuan organisme untuk mengeluarkannya, dimana hal ini di sebut sebagai bioakumulasi. Jalur utama manusia terpapar yaitu dari konsumsi makanan yang berasal dari laut yang terakumulasi oleh merkuri organik (Kaercher et al., 2005).

Penelitian sebelumnya yang telah dilakukan oleh Simangge, (2011) menyatakan bahwa beberapa jenis ikan yang telah diteliti di Teluk Kao dalam tingkatan membahayakan karena mengandung sianida. Sumber protein lain yang telah banyak dimanfaatkan oleh masyarakat sekitar Teluk Kao yaitu kerang Kepah. Berdasarkan hal inilah peneliti ingin mengkaji kandungan merkuri dan asam sianida pada kerang kepah Polymasoda sp yang di konsumsi oleh masyarakat sekitar Teluk Kao. Dengan mengetahui hasil kajian ini diharapkan hal dapat mengartikan tingkat keamanan kerang kepah Polymasoda sp layak tidaknya untuk dikonsumi oleh manusia. 


\section{BAHAN DAN METODE}

Penelitian kandungan merkuri dan asam sianida pada Polymesoda sp di Teluk Kao dilakukan pada tahun 2016, pengambilan data lapangan dan laboratorium dilakukan selama 4 bulan (bulan Juni sampai September). Lokasi pengambilan sampel kerang dilakukan pada tiga stasiun: pertama yaitu kawasan tanpa pertambangan, kedua yaitu kawasan PETI, ketiga kawasan PT NHM. Penelitian terdiri atas 3 tahapan yaitu: tahap pertama yaitu pengambilan sampel Polymesoda sp dilapang. Tahap kedua yaitu analisis laboratorium kandungan merkuri pada kerang dengan menggunakan metode AAS dengan menggunakan pereaksi aquaregia dan analisis kandungan asam sianida pada kerang dengan menggunakan metode argentometri dengan pereaksi $\mathrm{AgNO}_{3}$. Tahap ketiga analisis data, sampel hasil analisis laboratorium dibandingkan dengan nilai ambang batas merkuri dan asam sianida yang diperbolehkan oleh aturan yang berlaku melalui studi literatur sehingga diperoleh suatu kesimpulan layak tidaknya Polymesoda sp di Teluk Kao untuk dikonsumsi.

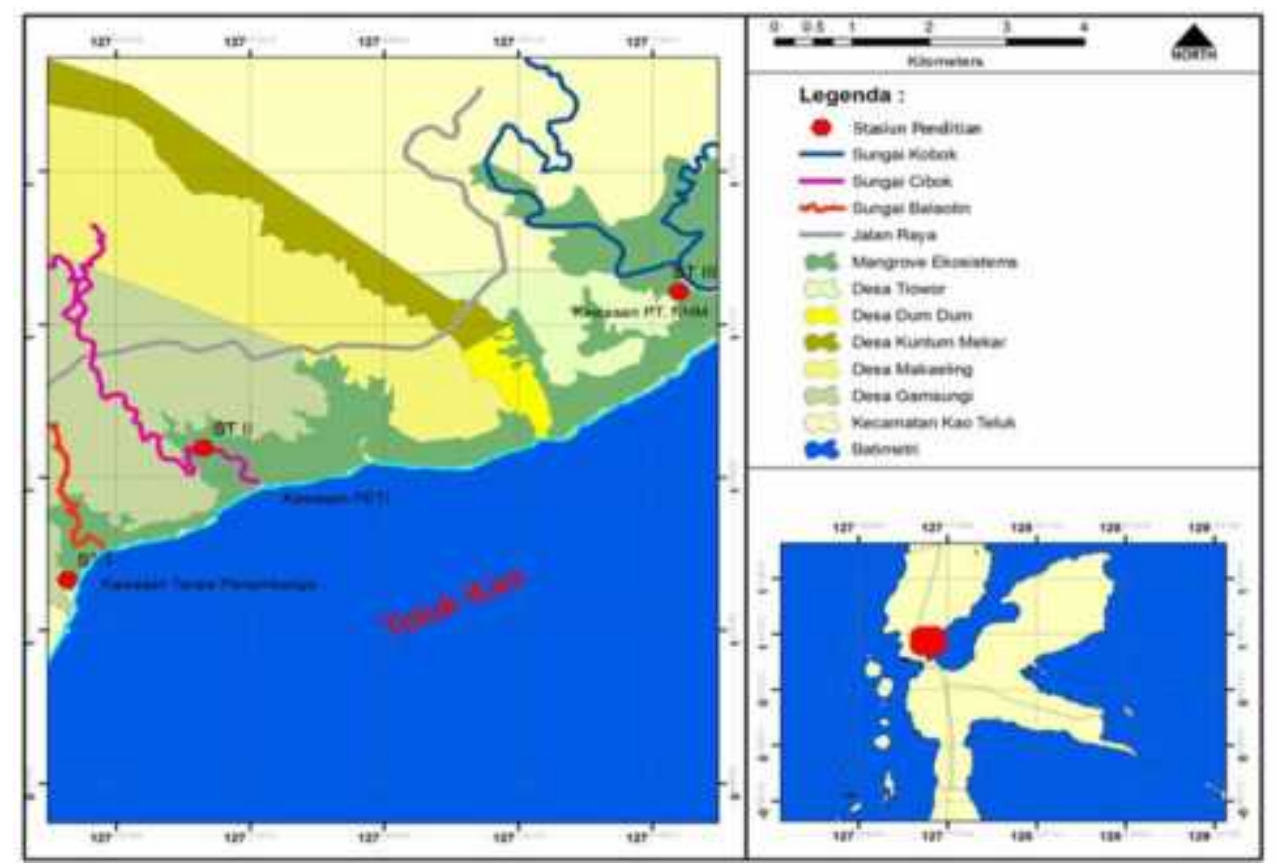

Gambar 1. Peta Lokasi Pengambilan Sampel

(Data Primer, 2016)

\section{HASIL DAN PEMBAHASAN}

Masyarakat Maluku Utara menyebut kerang kepah sebagai kerang kodok. Kerang ini menjadi salah sumber pendapatan masyarakat pesisir di sekitar Teluk Kao karena dapat diperjual belikan di pasar lokal, sebagai sumber protein hewani yang dikomsumsi. Berdasarkan hasil sampling yang didapatkan, jumlah Polymesoda sp. yang ditemukan sangat sedikit, sehingga sampel dianalisis berdasarkan kesamaan berat basah masing-masing kerang pada tiap-tiap lokasi sampling. Berikut hasil analisis uji laboratorium kandungan asam sianida pada tiap stasiun dapat lihat pada Tabel 1. 
TECHNO: Vol. 07 ( 01) Mei 2018

Tabel 1. Hasil Analisis kandungan merkuri dan asam sianida pada Polymesoda sp di Teluk Kao

\begin{tabular}{cccc}
\hline Stasiun & Kandungan $\mathrm{Hg}$ & Kandungan HCN & Satuan \\
\hline 1. & $3,49 \pm 0,55$ & $19,70 \pm 0,07$ & $(\mathrm{mg} / \mathrm{kg})$ \\
& $1,72 \pm 0,00$ & $21,98 \pm 1,41$ & $\mathrm{mg} / \mathrm{kg}$ \\
2. & $1,94 \pm 0,55$ & $15,16 \pm 0.01$ & $\mathrm{mg} / \mathrm{kg}$ \\
& $1,24 \pm 0,58$ & $24,11 \pm 1,27$ & $\mathrm{mg} / \mathrm{kg}$ \\
3. & $1,99 \pm 0,00$ & $14,55 \pm 0,02$ & $\mathrm{mg} / \mathrm{kg}$ \\
& $2,67 \pm 0,54$ & $18,79 \pm 0,04$ & $\mathrm{mg} / \mathrm{kg}$
\end{tabular}

Sumber: Data Primer, 2016

Hasil uji laboratorium menunjukkan bahwa kisaran kandungan merkuri pada keseluruhan Polymesoda sp di Teluk Kao yaitu 1.24-3.49 mg/kg (Tabel 1 dan Gambar 2). Hal ini berarti kandungan merkuri yang terdapat dalam kerang kepah sangat tinggi. Hal tersebut dimungkinkan terkait dengan besarnya konsentrasi merkuri yang digunakan dan dibuang dari proses ekstraksi emas yang dilakukan, serta analisis uji laboratorium yang dilakukan pada semua bagian Polymesoda sp.

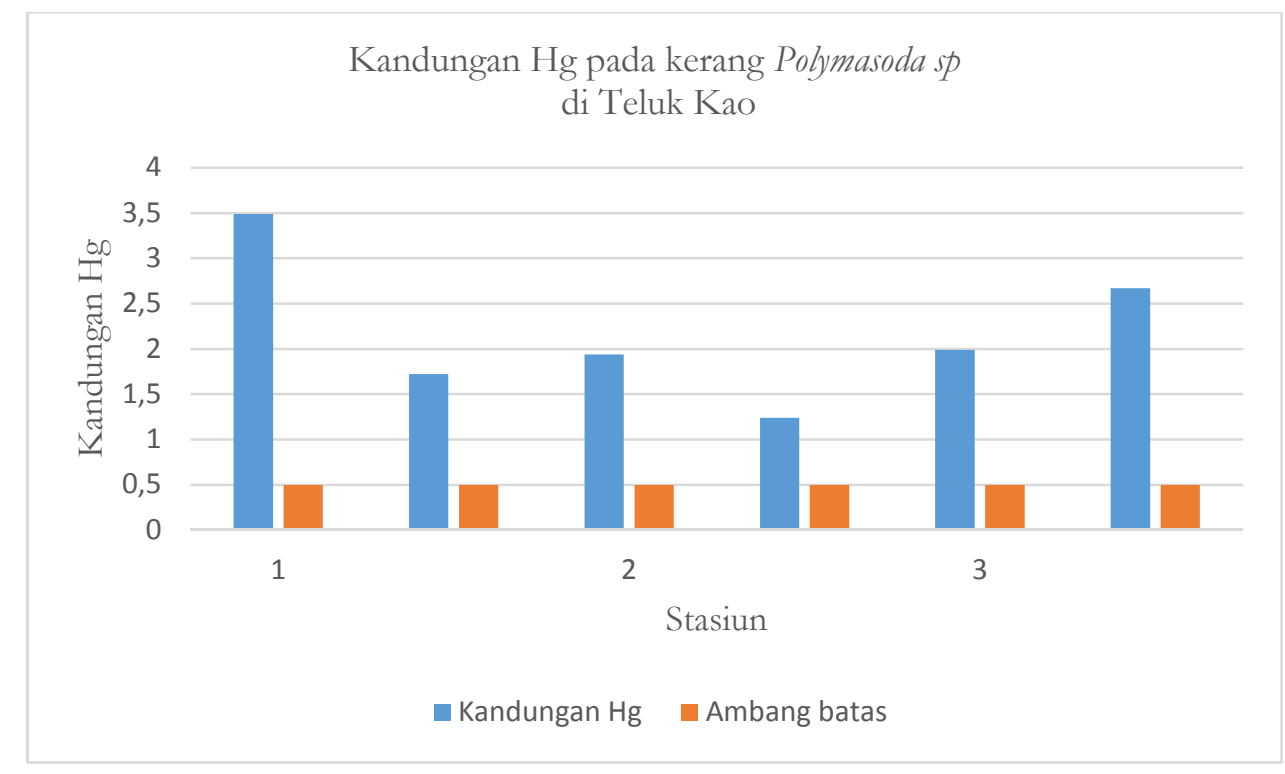

Gambar 2. Kandungan Merkuri pada kerang Polymesoda sp di Teluk Kao

Berdasarkan penelitian yang telah dilakukan oleh Simange (2011) menyatakan bahwa ikan biji nangka terkandung merkuri pada hati dan daging masing-masing sebesar $0.45-0.51 \mathrm{mg} / \mathrm{kg}$ dan $0.03-0.04 \mathrm{mg} / \mathrm{kg}$. Dengan demikian kandungan merkuri pada bagian daging ikan masih dapat untuk dikonsumsi, sedangkan pada hati ikan biji nangka telah mendekati ambang batas yang ditentukkan oleh FAO/WHO, (2004) sebesar $0.5 \mathrm{mg} / \mathrm{kg}$. Demikian juga pada kerang Polymesoda sp yang ditemukan di Teluk Kao $(0.45-0.51 \mathrm{mg} / \mathrm{kg})$ tidak layak untuk dikonsumsi karena kandungan merkuri yang terkandung di dalamnya sangat tinggi melebihi ambang batas yang telah ditetapkan oleh FAO, (2004) yaitu $0.5 \mathrm{mg} / \mathrm{kg}$. 
Reni, T.A.P. Asam Sianida, Merkuri, Polymesoda sp.

Hasil uji laboratorium menunjukkan bahwa kisaran kandungan asam sianida pada keseluruhan Polymesoda sp di Teluk Kao yaitu 14.55-24.11 mg/kg (Tabel 1 dan Gambar 3). Hal ini berarti kandungan asam sianida yang terdapat dalam kerang kepah sangat tinggi. Hal tersebut dimungkinkan terkait dengan besarnya konsentrasi sianida yang digunakan dan dibuang dari proses ekstraksi emas yang dilakukan, serta analisis uji laboratorium yang dilakukan pada semua bagian Polymesoda sp tidak pada bagian tertentu seperti hati, daging serta insang.

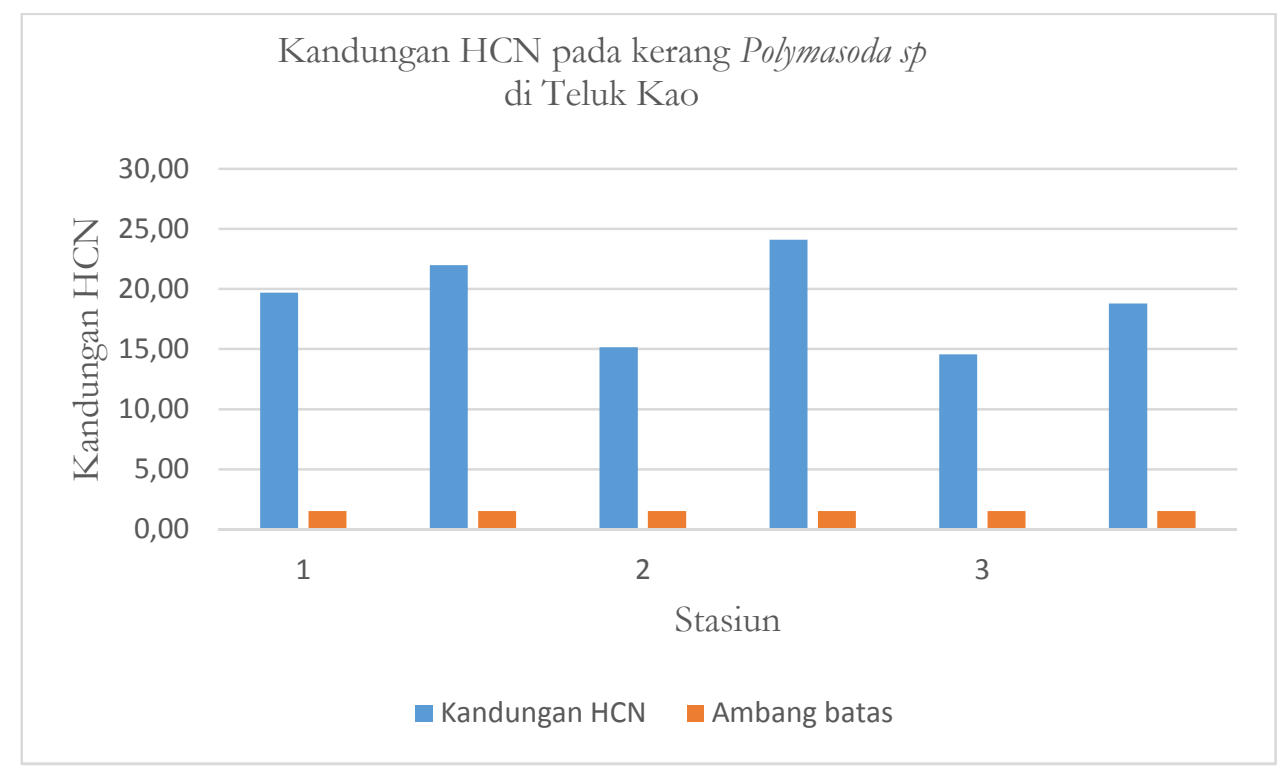

Gambar 3. Kandungan Asam Sianida pada kerang Polymesoda sp di Teluk Kao

Kandungan asam sianida tertinggi ditemukan pada stasiun 2 yaitu $24.11 \mathrm{mg} / \mathrm{kg}$ hal ini dimungkinkan Sungai Cibok merupakan penerima buangan limbah sianida dari daerah pertambangan. Menurut EPA (1978), sianida juga mengalami biokosentrasi kompleks pada ikan. Dampaknya selain pada biota air juga dapat berpengaruh pada manusia yang mengkonsumsi biota yang mati seperti ikan, kerang dan udang, karena senyawa racun dalam tubuh ikan akan terakumulasi dalam tubuh manusia. Toksisitas sianida sangat dipengaruhi oleh oksigen terlarut, $\mathrm{pH}$, dan temperatur perairan. Ambang batas sianida dalam pangan yang ditetapkan oleh FAO dalam Darmono, (2008) adalah $1.52 \mathrm{mg} / \mathrm{kg}$. Berdasarkan penelitian yang telah dilakukan oleh Simange (2011) menyatakan bahwa ikan kakap merah, ikan belanak, dan udang putih pada bagian daging dan hati yang ditangkap disekitar Teluk Kao memiliki konsentrasi kandungan sianida yang melebihi ambang batas konsumsi yaitu $6,0-12,3 \mathrm{mg} / \mathrm{kg}$, sehingga ikan tersebut tidak layak untuk dikonsumsi. Polymesoda sp yang ditemukan di Teluk Kao melebihi ambang batas yang telah ditetapkan yaitu 14.55 - 24.11 $\mathrm{mg} / \mathrm{kg}$. Hal ini juga dapat diasumsikan bahwa Polymasoda sp hidupnya relatif menetap atau pergerakannya terbatas sehingga menerima asupan limbah sianida dalam jumlah yang besar yang terakumulasi di jaringan tubuhnya. Sehingga dapat disimpulkan bahwa Polymesoda sp yang ditemukan di Teluk Kao tidak layak untuk dikonsumsi. 


\section{KESIMPULAN}

Kandungan merkuri dan asam sianida pada Polymesoda sp di Teluk Kao telah melebihi ambang batas yang telah ditetapkan. Kerang kepah Polymesoda sp di Teluk Kao tidak layak untuk dikonsumsi.

\section{REKOMENDASI}

Pengambilan sampel ikan atau kerang dilakukan dengan menganalisa organ target dalam tiap bulan agar di dapatkan akumulasi atau diketahui magnifikasi yang terjadi di tubuh biota terutama ikan yang bernilai ekonomis.

\section{DAFTAR PUSTAKA}

Darmono, 2008. Lingkungan Hidup dan Pencemaran : Hubungannya dengan toksikologi senyawa logam. UI-Press. Jakarta.

EPA, 1978. U.S, Environmental Protection Agency. Code of Federal Regulation 40 CFR 180.3

FAO/WHO, 2004. Summay of Evaluations Ferformade by Jint FAO/WHO Expert Committee of Food Additives (JECFA 1956-2003). ILSI Press International Life Science Institutes.

Kaercher, L.E, Goldsmicth, F., Paniz, J.N.G., Flores, E.M.M., Dressler, V.L., 2005. Determination of inorganic and total mercury by vapor generation atomic absorption spectrometry using different temperatures of the measurement cell. Spectrochimica Acta Part B 60 (5), 705-710.

Matta, J., Milad, M., Manger, R., and Tosteson, T. 1999. Heavy metals, lipid peroxidation and cigateratoxicity in the liver of Caribben barracuda (Sphyraena barracuda). Biological Trace Element Research. 70. 69-79.

Marti Cid R, Anan Bocia, Juan M. Llobet, Jose L. Domingo, 2007. Intake of chemical contaminants through fish and seafood consumption by children of Catalonia, Spain: Health risks. ScienceDirect, Food and Chemical Toxicology 45 (2007) 1968-1974.

Murata K, P. Grandjean, M. Dakeishi, 2007. Neurophysiological evidence of methylmercury neurotoxicity. Am J. Ind. Med 50. 765-771.

Niazi, A., Momeni-Isfahani, T., Ahmari, Z., 2009. Spectrophotometric determination of mercury in water samples after cloud point extraction using nonionic surfactant Triton X-114. Journal of Hazardous Materials 165, 1200-1203.

Simangge, S.M, 2011. Analisis kandungan merkuri dan sianida pada beberapa jenis ikan hasil tangkapan nelayan di Teluk Kao Kabupaten Halmahera Utara. Jurnal Agroforestri Vol VI (2). ISSN 1907-7556 : 103-108.

Ye B.C, Yin B.C. 2008. Highly sensitive detection of mercury (II) ions by fluorescence polarization enhanced by gold nanoparticles. Angewandte Chemie. International Edition. 47.8386-8389. 